\title{
ТЕНДЕНЦІЇ В ПОШИРЕННІ ВІДКЛАДЕНЬ ОЖЕЛЕДІ НА ТЕРИТОРІЇ УКРАЇНИ ПРОТЯГОМ 1991-2000 РР., 2001-2010 РР. ТА НА СУЧАСНОМУ ЕТАПІ ЗМІНИ КЛІМАТУ (2011-2019 РР.) У МІСЯЦІ ХОЛОДНОГО ПЕРІОДУ РОКУ ТА ОКРЕМІ МІСЯЦІ ПЕРЕХІДНИХ СЕЗОНІВ
}

\section{Пясецька C. I.}

\section{ВСТУП}

Відкладення ожеледі є одним із несприятливих погодних явищ на території України протягом місяців холодного періоду року та в окремі місяці перехідних сезонів. Вони спостерігаються кожного року, причому найбільш масштабно проявляються в зимові місяці особливо в грудні та січні. Саме в ці місяці зазвичай такі відкладення частіше набувають масового поширення. Відкладення ожеледі дуже часто перешкоджають безперебійній роботі низки галузей економіки, особливо тих, які найбільш залежні від них. Це, насамперед, енергетична галузь, транспорт, комунальна сфера та зелене господарство. Особливо великих втрат ці галузі зазнають тоді, коли такі відкладення сягають найбільшого розвитку та переходять у категорію небезпечних (НЯ) та стихійних (СГЯ). Актуальність дослідження їх просторового поширення набуває нового сенсу на сучасному етапі зміни клімату в Україні, який пов'язаний із глобальним потеплінням, яке найбільше проявляється в холодний період року та потенційно призводить до збільшення випадків ожеледопаморозевих відкладень. Предметом дослідження є поширення відкладень ожеледі, які були спостережені інструментально на дротах стандартного ожеледного станка на території України протягом окремих періодів часу - 1991-2000 pp., 2001-2010, 2011-2015 рр. та на сучасному етапі зміни клімату 2011-2019 рр.

Отримані результати можуть бути використані для визначення кліматовразливих регіонів від таких відкладень та динаміки їх поширення натепер та в майбутньому для забезпечення сталого розвитку економіки держави.

Дослідження фізико-географічних особливостей просторового розподілу ожеледопаморозевих відкладень на території України було започатковано в роботах А.М. Раєвського та М.М. Волевахи ${ }^{1}$. В основу

\footnotetext{
${ }^{1}$ Волеваха Н.М. О влиянии орографии на гололедные отложения. Труды УкрНИГМИ. Вып. 13. С. 82-86; Раевский А.Н. Влияние рельефа на распределение гололедно-изморозевых отложений. Труды ОГМИ. 1961. Вып. ХХІІІ. С. 3-10; Раевский А.Н. О распределении гололеда на территории Украины. Труды УкрНИГМИ. 1961. Вып. 29. С. 50-62; Прохоренко М.М., Раевский А.Н. Особенности 634
} 
типізації було покладено низку умов: порівняна висота місцевості, ступінь захищеності щодо переважаючих вітрів, експозиції макросхилу місцезнаходження пункту спостереження. Таким чином, було встановлено 7 основних типів рельєфу та визначено, що V-VII типи рельєфу є найбільш ожеледонебезпечними (значно пересічений рельєф, перевищення висоти окремих ділянок 50 м та більше, наявність повздовжніх долин). У подальших роботах співробітників Українського гідрометеорологічного інституту О.М. Кошенка, колективом авторів під керівництвом Г.Ф. Приходько, К.Т. Логвинова та В.М. Бабіченко було досліджено особливості та стан поширення ожеледопаморозевих утворень на території України протягом кінця 30-60-х pp. XX ст. та до 70-х - початку 80-х pp. ${ }^{2}$. Було з'ясовано, що територіально максимального прояву відкладення ожеледі сягають у районі Донецького кряжу, Приазовської височини, Кримських горах (захід), ВолиноПодільській та Придніпровській височинах, Карпатах (північно-східні схили та високогір'я). Протягом цього часу найчастіше небезпечні відкладення ожеледі мали місце в районі Донецького кряжу, Приазовської височини та Криму. Наступним етапом дослідження поширення ожеледопаморозевих відкладень, зокрема ожеледі, були дослідження поширення таких відкладень стихійного характеру на території України. Результати цих досліджень було викладено в монографіях під керівництвом В.М. Бабіченко «Стихийные метеорологические явления на Украине и Молдавии» 1991 р. та «Клімат України» 2003 p. ${ }^{3}$ За даними матеріалів дослідження, які були наявні на той момент, було встановлено вірогідність прояву відкладень ожеледі стихійного характеру на Україні та виділено 4 райони: 1 - Донецька, Луганська, Вінницька, Кіровоградська, Одеська, Миколаївська області (1 раз за 2-3 роки); 2 - Тернопільська, Хмельницька, Полтавська, Харківська, Дніпропетровська, Херсонська області (1 раз за 5 років); 3 - Рівненська, Житомирська, Київська, Черкаська, Івано-Франківська, Запорізька області та АР Крим (1 раз на 10 років); 4 - Волинська, Чернігівська, Сумська, Львівська, Закарпатська, Чернівецька області (1 раз на 20 років). Останньою фундаментальною роботою 3 дослідження стихійних метеорологічних явищ на Україні, в тому числі і сильної ожеледі $\epsilon$ монографія «Стихійні метеорологічні явища на

распределения гололедноизморозевых отложений на территории Украины в аномальные зимы. Метеорология, климатология и гидрология. 1975. Вып. 11. С. 33-37.

2 Климат Украины / Под ред. Г.Ф. Прихотько, А.В. Ткаченко, В.Н. Бабиченко. Ленинград : Гидрометеоиздат, 1967. 413 с.; Опасные явления погоды на Украине / Под ред. К.Т. Логвинова. Трудbl УкрНИГМИ. 1972. Вып. 110. 235 с.; Природа Украинской ССР. Климат / Под ред. К.Т. Логвинова, М.И. Щербаня. Киев : Наукова думка, 1984. 231 с.

${ }^{3}$ Стихийные метеорологические явления на Украине и Молдавии / Под ред. В.Н. Бабиченко. Ленинград : Гидрометеоиздат, 1991. 223 с.

Клімат України / За ред.. В.М. Ліпінського, В.А. Дячука, В.М. Бабіченко. Київ : Вид-во. Раєвського, 2003. 343 с. 
території України за останнє двадцятиріччя (1986-2005рр.)», в якій досліджено стан інтенсивності та поширення стихійних явищ протягом 1985-2005 pp. Дослідження поширення відкладень ожеледі на території України на сучасному етапі зміни клімату продовжено автором у низці poбiт $^{5}$. Натепер постає задача встановити сучасні тенденції в поширенні відкладень ожеледі, у тому числі небезпечного та стихійного характеру на території України через зміну клімату.

Для встановлення тенденцій у зміні кількості випадків відкладень ожеледі в низці місяців протягом певних часових періодів було здійснено порівняння їх середньої кількості в цих періодах з отриманням відхилень. Відхилення визначались як різниця між середніми значеннями періоду, для якого визначається тенденція, щодо середніх значень попереднього періоду, з ким проводиться порівняння. Значення відхилень можуть бути додатними, якщо середня кількість випадків елементу, що визначається в поточному періоді більше, ніж у тому щодо якого поводиться порівняння, а також від'ємними, якщо їх кількість менша. За отриманою інформацією для кожного досліджуваного місяця створювались карти просторового поширення таких відхилень, які формували відповідні осередки додатних та від’ємних відхилень.

\section{1. Тенденції у поширенні відкладень ожеледі на території України протягом 2001-2010 та 2001-2015 рр. порівняно з 1991-2000 pp.}

Січень. Проведеним дослідженням встановлено, що порівняно 3 періодом 1991-2000 pp. у 2001-2010 pр. та 2011-2015 pр. у більшості областей (16 та 21 відповідно) на станціях переважали додатні відхилення середньої кількості випадків із відкладенням ожеледі. Від’ємні відхилення переважали на станціях лише у 7 областях Волинській, Львівській, Хмельницькій, Закарпатській, Чернігівській та Луганській областях у 2001-2010 рр., у Миколаївській області у 2011-2015 рр. Також встановлено, що в окремих областях кількість станцій із додатними та від'ємними відхиленнями була рівною - у 2001-2010 pр. у Київській області, а у 2011-2015 рр. у Луганській. Було визначено станції, де середня кількість випадків відкладень ожеледі протягом останнього десятиріччя та п'ятиріччя залишилася без змін («0» відхилення). Так, у 2001-2010 рр. такі станції були у 9 областях Львівській, Закарпатській, Чернівецькій, Київській, Кіровоградській, Одеській, Харківській, Луганській та АР Крим. У 2001-2015 рр. станції із «0» відхиленнями помічались у 7 областях - Львівській,

\footnotetext{
${ }^{4}$ Стихійні метеорологічні явища на території України за останнє двадцятиріччя (1986-2005 pp.) / За ред. В.М. Ліпінського, В.І. Осадчого, В.М. Бабіченко. Київ : Вид-во Ніка-Центр, 2006. 311 с.

${ }^{5}$ Пясецька С.І., Гребенюк Н.П., Щеглов О.А. Розподіл випадків відкладень ожеледі та небезпечної (НЯ) і стихійної (СГЯ) на території України в умовах сучасного клімату. Географія та туризм. 2018. Вип. 45. С. 120-132. DOI 17721/2308-135X.2019.45.120-132.
}

636 
Тернопільській, Закарпатській, Чернігівській, Полтавській, Харківській та АР Крим (рис. 1).

Найбільші 3 додатних відхилень $(+1,0 \ldots+1,9)$ середньої кількості випадків відкладень ожеледі порівняно з періодом 1991-2000 pp. у 2001-2010 рр. помічались на окремих станціях у 10 областях. Максимальні 3 додатних відхилень становили $+2,1$ і спостерігались у 2 областях - Харківській та Донецькій. Найнижчі з від'ємних відхилень $(-1,2$ та $-1,3)$ спостерігались на станціях лише у Хмельницькій області. У 2001-2015 рр. порівняно з 1991-2000 рр. найбільші з додатних відхилень $(+1,0 \ldots+1,9)$ середньої кількості випадків із відкладенням ожеледі помічались на станціях у 16 областях. Максимальні з додатних відхилень $(+2,1 \ldots+2,8)$ виявлено на станціях у трьох областях Тернопільській, Кіровоградській, Полтавській. Найнижчі з від'ємних відхилень $(-1,0 \ldots-1,2)$ спостерігались у 3 областях - Закарпатській, Миколаївській, АР Крим.

Лютий. Порівняно з періодом 1991-2000 pp. у наступному десятиріччі 2001-2010 рр. на станціях України здебільшого переважали додатні відхилення середньої кількості випадків відкладень ожеледі. Найбільші значення додатних відхилень $(+1,0 \ldots+1,5)$ помічаються на станціях 11 областей на заході, півночі центрі та сході країни. Найнижчі значення від'ємних відхилень $(-1,0)$ спостерігались у АР Крим (Владиславівка) (рис. 1). У 2001-2015 рр. порівняно з 1991-2000 pp. у більшості областей (15) переважали станції з додатними відхиленнями середньої кількості випадків відкладень ожеледі, а у 10 областях, навпаки, переважали станції із від'ємними відхиленнями. Також у низці областей середня кількість випадків відкладень ожеледі не змінилась. Найбільші 3 додатних відхилень $(+1,0 \ldots+1,7)$ помічались на окремих станціях у 4 областях - Тернопільській, Закарпатській, Чернігівській та Одеській. Найнижчі з від'ємних відхилень $(-1,1 \ldots-1,4)$ спостерігались у цей час на окремих станціях у Запорізькій області та АР Крим, а також максимальне значення (-2,2) у Херсонській області У 2001-2015 pp. порівняно з 1991-2000 pp. У більшості областей (15) переважали станції 3 додатними відхиленнями середньої кількості випадків відкладень ожеледі, а у 10 областях, навпаки, переважали станції з від'ємними відхиленнями. Також у низці областей середня кількість випадків відкладень ожеледі не змінилась. Найбільші 3 додатних відхилень $(+1,0 \ldots+1,7)$ помічались на окремих станціях у 4 областях Тернопільській, Закарпатській, Чернігівській та Одеській. Найнижчі 3 визначених від'ємних відхилень $(-1,1 \ldots-1,4)$ спостерігались у цей час на окремих станціях у Запорізькій області та АР Крим, а також найнижче значення $(-2,2)-$ у Херсонській області. 


\section{Січень}
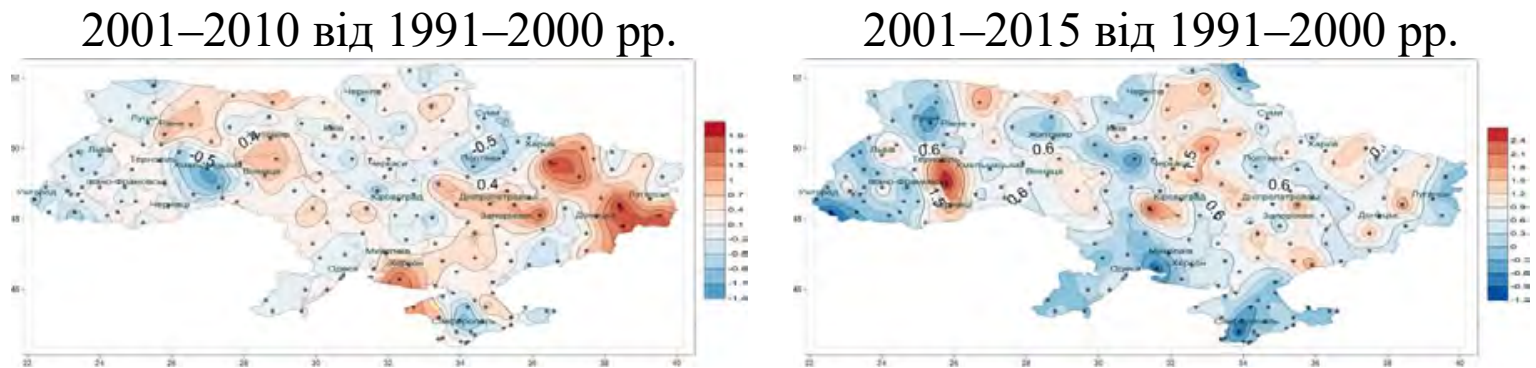

\section{Лютий}

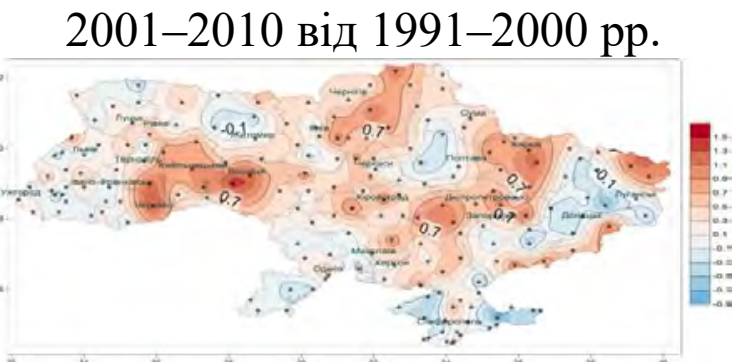

2001-2015 від 1991-2000 pp.

Березень
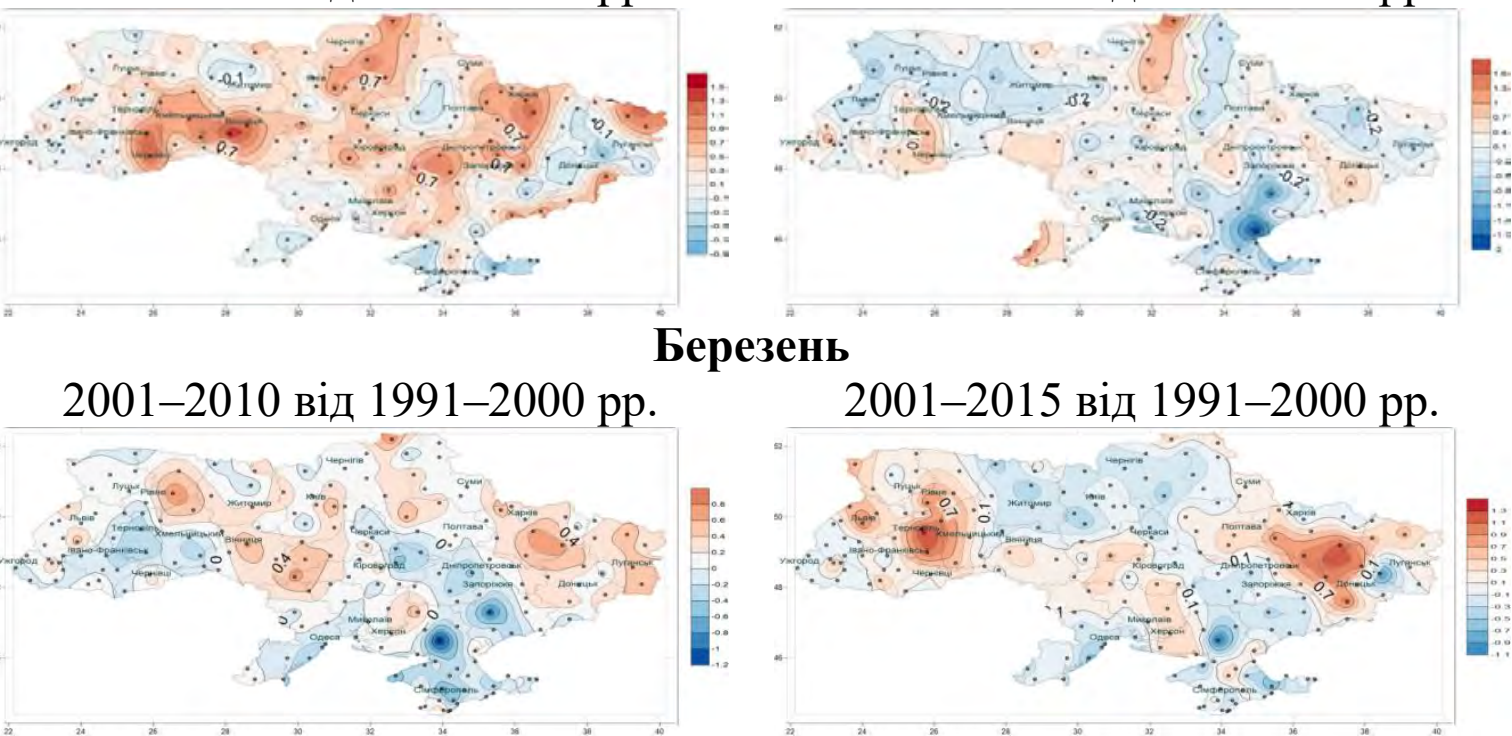

\section{Листопад}

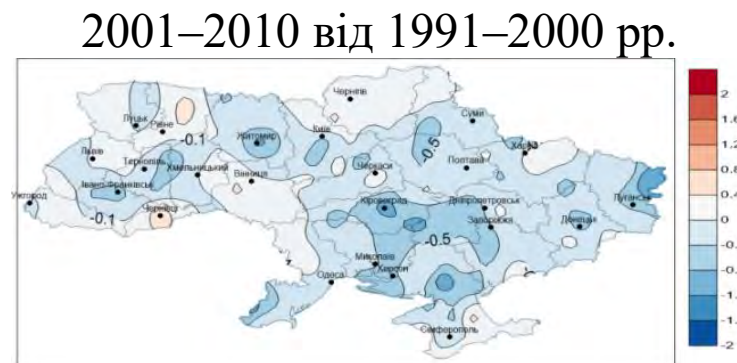

2001-2015 від 1991-2000 pp.
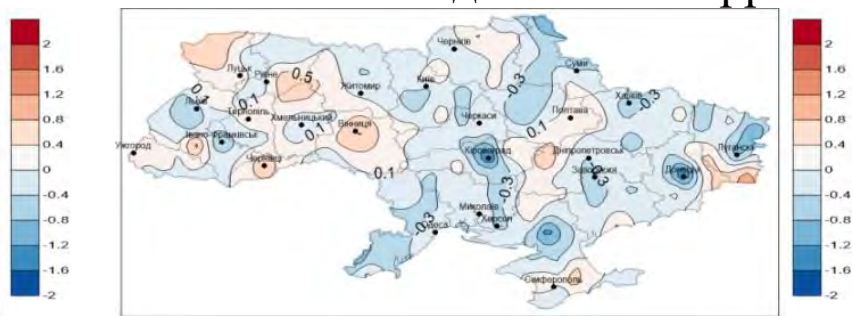

\section{Грудень}
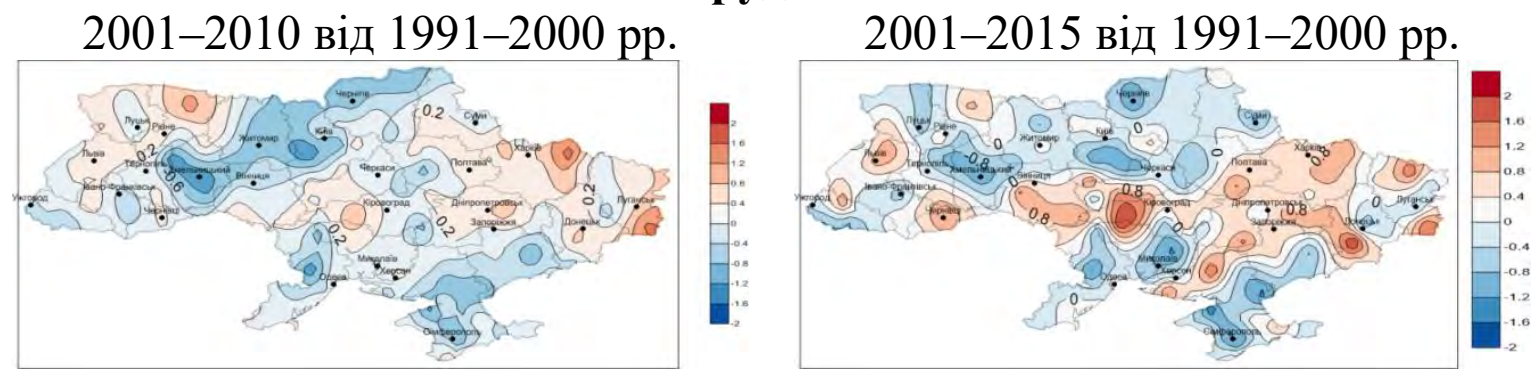

Рис. 1. Відхилення середньої кількості випадків із відкладеннями ожеледі за періоди: 2001-2010 та 2001-2015 порівняно з 1991-2000 pp. 
Березень. Порівняно 3 періодом 1991-2000 pp. у 2001-2010 та 2001-2015 pр. у більшості областей на станціях переважали додатні відхилення середньої кількості випадків із відкладенням ожеледі. Так, у 2001-2010 pр. у 13 областях на більшості станцій переважали додатні відхилення середньої кількості випадків відкладення ожеледі. Виключенням стали Хмельницька, Івано-Франківська, Одеська області та АР Крим, де переважали станції з від'ємними відхиленнями, а також Рівненська, Дніпропетровська, Кіровоградська та Запорізька області, де станцій із додатними та від'ємними відхиленнями було порівну. Також станції, де середня кількість випадків із відкладенням ожеледі не змінилась, порівняно 3 періодом порівняння (1991-2000рр.) спостерігались у більшості областей, окрім 6 - Хмельницької, Тернопільської, Івано-Франківської, Житомирської. Кіровоградської та Луганської (рис. 1). У 2001-2015 pр. порівняно 3 періодом 19912000 pp., як і у 2001-2010 pp., у 15 областях переважали станції 3 додатними відхиленнями середньої кількості випадків із відкладенням ожеледі. Найбільші з них становили $+0,6 \ldots+0,8$ і спостерігались на окремих станціях в областях - Рівненській, Закарпатській, Чернігівській, Київській, Вінницькій, Кіровоградській, Полтавській та Харківській. Від'ємні відхилення переважали на станціях у 7 областях Чернівецькій, Чернігівській, Житомирській, Київській, Одеській, Запорізькій та АР Крим. Найнижчі з від’ємних відхилень $(-1,0 \ldots-1,4)$ помічались на станціях у Херсонській та Запорізькій областях. На заході, у центрі та подекуди на півдні країни виявлено станції, де середня кількість випадків із відкладеннями ожеледі залишилась незмінною. У період 2001-2015 pр. порівняно з періодом 1991-2000 pp. найбільші з додатних відхилень становили $+1,0 \ldots+1,8$. Вони помічались на станціях у Рівненській, Львівській, Тернопільській, Харківській та Донецькій областях. Найнижчі з від'ємних відхилень (1,1 та -1,3) помічались, відповідно, у Донецькій та Херсонській областях.

Квітень. Порівняно з 1991-2000 pр. у наступних періодах також по областях здебільшого переважають станції із незмінною середньою кількістю випадків відкладень ожеледі. Винятком $є$ Сумська та Харківська, де переважали станції з від'ємними відхиленнями протягом 2001-2010 та 2001-2015 pp., а також у Хмельницькій області, де у 2001-2015 рр. станцій із від'ємними відхиленнями було більше, ніж із додатними. 3 огляду на те, що кількість випадків відкладень ожеледі наприкінці весни невелика i такі відкладення спостерігаються здебільшого поодиноко, цей місяць не відображено на рис. 1.

Жовтень. Порівняно 3 періодом 1991-2000 pp. у наступному десятиріччі 2001-2010 pp. у більшості областей переважають станції, на яких середня кількість випадків із відкладеннями ожеледі не змінилась. 
У 2001-2015 рр. порівняно з 1991-2000 рр. встановлено переважання станцій із додатними відхиленнями середньої кількості випадків із відкладеннями ожеледі в 11 областях на заході, центрі та окремих областях півдня. Так само, як і у квітні, на рис. 1 просторовий розподіл таких відкладень не відображався, з огляду на специфіку їх поширення.

Листопад. Порівняно 3 1991-2000 рр. у наступному десятиріччі 2001-2010 pp. у більшості областей (19) переважають станції 3 від'ємними відхиленнями, тільки в Рівненській та Чернігівській областях переважали станції із додатними відхиленнями. Ще у трьох областях - Волинській, Чернівецькій та Вінницькій - кількість станцій із додатними та від'ємними відхиленнями була рівною. У 2001-2015 рр. по областях здебільшого переважали від'ємні відхилення (13), а областей, де переважали додатні відхилення, було лише 5 і розташовані вони переважно на заході або півночі. У Кіровоградській області спостерігалась ситуація, коли станцій із додатними та від'ємними відхиленнями було порівну (рис. 1.)

За величиною додатні відхилення у 2001-2010 pp. порівняно 3 1991-2000 pр. були незначні (до $+0,4$ ), і тільки у Чернівцях вони становили $+0,6$. Найнижчі з від'ємних відхилень становили $-1,1 \ldots-1,4$ і спостерігались у 6 областях - Житомирській, Кіровоградській, Одеській, Херсонській, Луганській, Дніпропетровській. У 2001-2015 рр. найбільші 3 додатних відхилень становили $+0,6 \ldots+0,8$ та спостерігались в 11 областях. Максимальні додатні відхилення $(+1,0 \ldots+1,2)$ спостерігались у трьох областях - Івано-Франківській, Вінницькій та Луганській. Найнижчі з від'ємних відхилень становили $-1,0 \ldots-1,8$. Вони спостерігались у 6 областях - Кіровоградській, Одеській, Херсонській, Сумській, Луганській, Донецькій.

Грудень. Порівняно 3 періодом 1991-2000 рр. у 2001-2010 рр. у 14 областях переважали станції з від'ємними відхиленнями середньої кількості випадків із відкладеннями ожеледі. Кількість областей, де переважали додатні відхилення, збільшилось до 10: це Волинська, Рівненська, Львівська, Тернопільська, Кіровоградська, Сумська, Полтавська, Харківська, Луганська, Дніпропетровська області. У 2001-2015 рр. порівняно 3 1991-2000 рр. станції з додатними відхиленнями переважали у 9 областях, причому, на відміну від 2001-2010 pp., у Чернігівській, Житомирській та Вінницькій областях. Станції із від'ємними відхиленнями переважали у 12 областях, причому, на відміну від 2001-2010рр., у Волинській, Миколаївській, Сумській областях. У Тернопільській, Івано-Франківській, Луганській та Донецькій областях станцій із додатними та від'ємними відхиленнями було порівну (рис. 1). 
Порівняно з 2001-2010 pp. у 2001-2015 pp. у більшості областей (15) переважали станції з додатними відхиленнями. Областей, де на станціях переважали від'ємні відхилення, було 8 - Волинська, Рівненська, Закарпатська, Одеська. Миколаївська, Сумська, Харківська та АР Крим. Ще у двох областях - Тернопільській та Луганській - станцій із додатними та від'ємними відхиленнями було порівну.

Найбільші 3 додатних відхилень у 2001-2010 pp. порівняно 3 1991-2000 pр. здебільшого становили $+0,6 \ldots+0,9$ і спостерігались у 10 областях - Волинській, Рівненській, Львівській, Кіровоградській, Миколаївській, Сумській, Харківській, Луганській, Донецькій, Дніпропетровській. Відхилення $+1,1 \ldots+1,7$ спостерігались у Харківській, Луганській областях. Найнижчі 3 від'ємних відхилень становили $-1,0 \ldots-1,4$ і спостерігались у 10 областях, причому найбільше у Хмельницькій області, Київській, Одеській. У 2001-2015 рр. найбільші 3 додатних відхилень становили $+1,0 \ldots+1,6$. Вони спостерігались у 15 областях, але найбільше у Львівській області, Закарпатській, Черкаській, Кіровоградській, Херсонській, Луганській, Дніпропетровській. Максимальні додатні відхилення становили $+2,1$ та $+2,3$, які спостерігались у Первомайську та Волновасі.

\section{2. Сучасні тенденції у поширенні відкладень ожеледі на території України протягом 2001-2015 рр. та 2011-2019 pp. порівняно з 2001-2010 pp.}

Січень. Порівняно 3 2001-2010 pp. в останньому п'ятиріччі 2001-2015 pр. по областях спостерігались додатні відхилення середньої кількості відкладень ожеледі. Від'ємні відхилення на станціях переважали лише в Рівненській та Миколаївській областях. Також у низці областей - Львівській, Івано-Франківській, Закарпатській, Чернігівській, Черкаській, Харківській - $є$ станції, де середня кількість випадків із відкладеннями ожеледі залишилась незмінною.

Встановлено, що найбільші 3 додатних відхилень $(+1,0 \ldots+1,9)$ середньої кількості випадків із відкладеннями ожеледі помічались на станціях у 16 областях. Максимальні значення додатних відхилень становили $+2,2 \ldots+2,6$ і спостерігались на окремих станціях у Хмельницькій, Тернопільській, Чернігівській, Запорізькій областях. Найнижчі з розрахованих від'ємних відхилень $(-1,0 \ldots-1,6)$ помічаються в 7 областях - Закарпатській, Миколаївській, Херсонській, Луганській, Донецькій, Дніпропетровській та АР Крим.

Для подальшого аналізу стану поширення відкладень ожеледі на території України, з огляду на різкі зміни клімату останнього часу, розглянуто тенденції в розподілі середньої кількості відкладень ожеледі 
у період 2011-2019 рр. (продовжений порівняно $з$ 2001-2015 рр.) у відхиленнях порівняно 3 попереднім періодом 2001-2010 рр. для визначення їх тенденцій, що спостерігаються на сучасному етапі зміни клімату, що пов'язано з розподілом температурних аномалій.

Так, у січні 2011-2019 рр. найбільш значні осередки 3 додатними відхиленнями спостерігаються на сході України: у Харківській (Коломак $+2,7)$, Донецькій (Волноваха $+2,1)$ областях. Осередки з дещо меншими додатними відхиленнями спостерігаються на півночі та північному сході на Чернігівщині, особливо в районі Чернігова та Сновська (Щорс), а також на більшій частині території Кіровоградщини (східна та південносхідна частини), півночі Полтавщини, південно-західної частини Дніпропетровщини. На заході та північному заході найбільш помітний осередок додатних відхилень середньої кількості випадків відкладення ожеледі із найбільшими значеннями таких відхилень спостерігається на території Тернопільської (Чортків $+2,2$ ), Чернівецької (Чернівці $+1,4$ ), Закарпатської (Нижні Ворота $+1,3$ ), Хмельницької (Нова Ушица $+1,3$ ) областей. На північному заході країни осередок додатних відхилень спостерігається на півночі Житомирської (Словечансько-Овручський кряж), Рівненської та Волинської областей. Окремий осередок додатних відхилень спостерігається поблизу Львова на півдні Розточчя. У південному регіоні в низці місць також спостерігається деяке збільшення кількості відкладень ожеледі - на Запоріжжі (Мелітополь, Ботієве +1,7), Одещині (східна частина), півночі Миколаївщини, північно-східній частині Херсонщини. На сході також спостерігаються окремі осередки додатних відхилень на півночі Луганщини та на південному сході Донеччини в районі Маріуполя та Волновахи. Зменшення кількості випадків відкладень ожеледі протягом січня у 2011-2019 рр. порівняно з 2001-2010 рр. спостерігалось в окремих регіонах на заході країни у центрі та півдні Рівненщини, на заході Львівщини, півдні Закарпаття (Берегове -1,0). Значний осередок із від'ємними відхиленнями спостерігався на території півдня Житомирщини, більшої частини Вінниччини та півдня Київщини (Фастів -0,6, Вінниця -0,6, Житомир -0,6). Окремі осередки від'ємних відхилень спостерігались у Сумській області в районі Хутора Михайлівського (Дружба) та Конотопа, на сході Харківщини, півночі на сході Дніпропетровщини, південному заході Запоріжжя (Генічеськ -0,9) та особливо на півдні Миколаївської (Миколаїв, Очаків -0,9) та крайньому заході Херсонської області, а також на півдні та південному заході Одещини (рис. 2). 


\section{Січень}
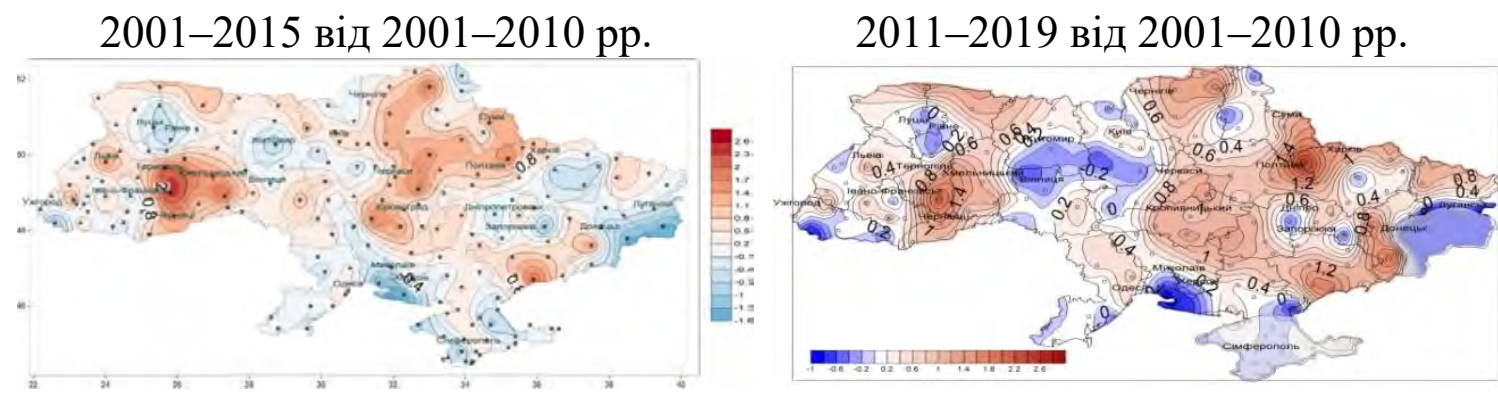

\section{Лютий}

2001-2015 від 2001-2010 pp.
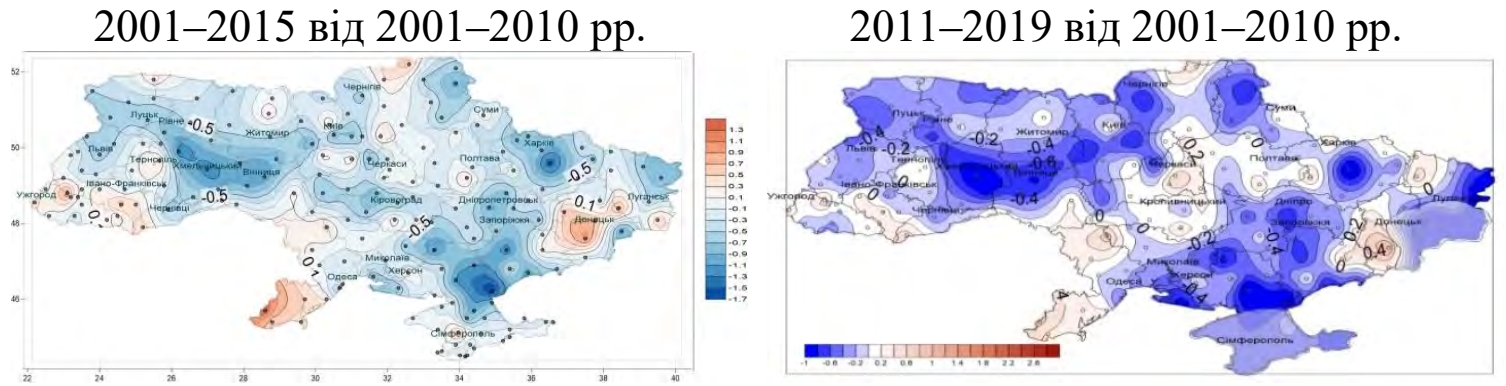

\section{Березень}

2001-2015 від 2001-2010 pp.

2011-2019 від 2001-2010 pp.
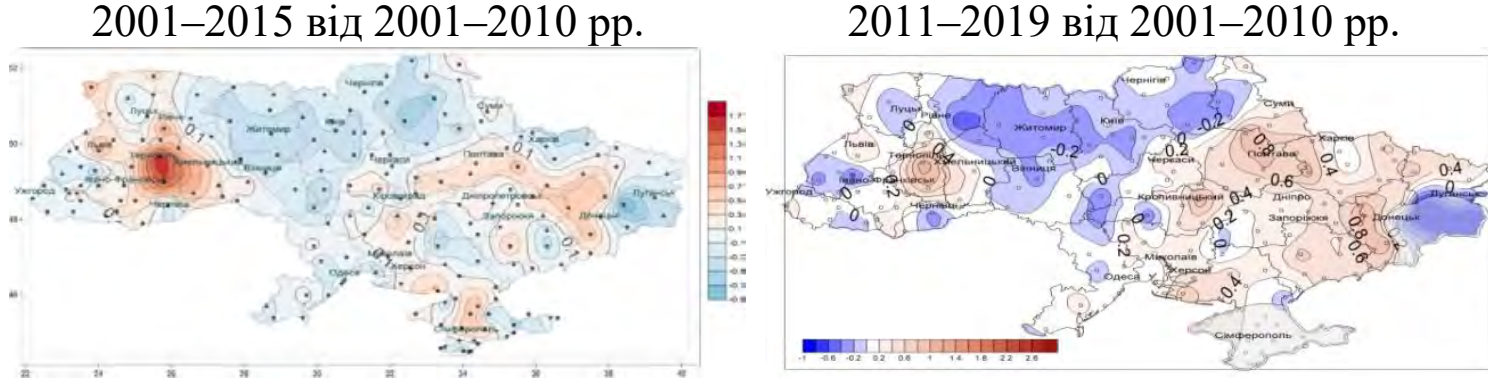

\section{Листопад}

2001-2015 від 2001-2010 pp.
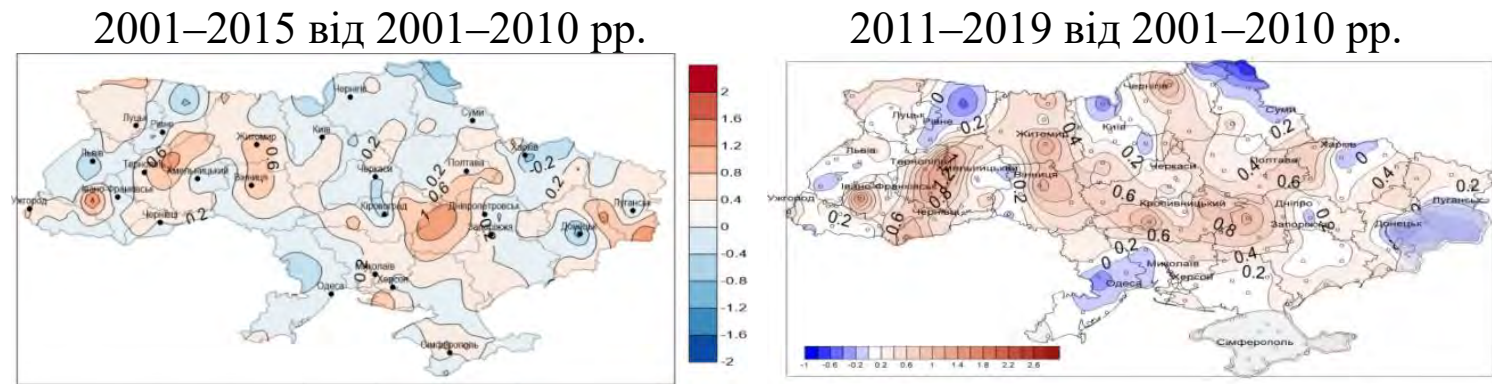

\section{Грудень}

2001-2015 від 2001-2010 pp.
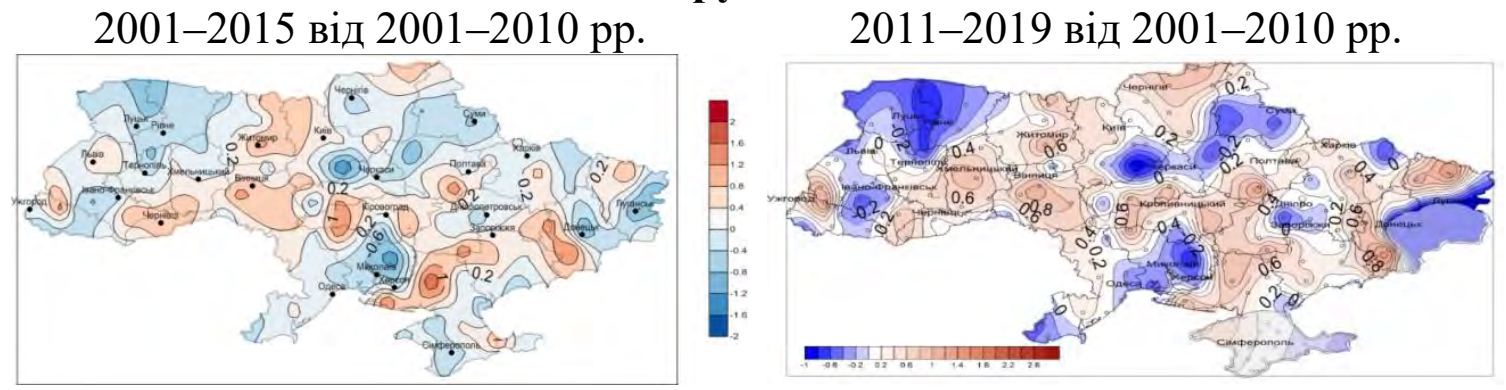

Рис. 2. Відхилення середньої кількості випадків ожеледі на дротах ожеледного станка за період 2001-2015 pp. та 2011-2019 порівняно з 2001-2010 pp. 
Лютий. Порівняно з періодом 2001-2010 рр. в останньому п’ятиріччі 2001-2015 рр. для більшості областей (12) характерні від'ємні відхилення. Додатні відхилення переважають на станціях в ІваноФранківській, Одеській та Донецькій областях. Крім того, у Закарпатській області кількість станцій із додатними відхиленнями та «0» була рівною, також у Полтавській області кількість станцій із додатними та від'ємними відхиленнями була рівною. Найбільші 3 додатних відхилень $(+1,0)$ середньої кількості випадків відкладення ожеледі помічались у Закарпатській області, а найнижчі 3 від'ємних $(-1,0 \ldots-1,8)$ - у Хмельницькій, Вінницькій, Херсонській, Донецькій Запорізькій.

У лютому 2011-2019 рр. порівняно 3 2011-2010 рр. переважають від'ємні відхилення середньої кількості відкладень ожеледі. Тобто на більшій частині території України прослідковується тенденція до зменшення кількості ожеледі. Один із двох потужних осередків від'ємних відхилень середньої кількості відкладень ожеледі простягнувся із заходу на схід від Львівської та Волинської областей у Хмельницьку, Житомирську, Рівненську, Київську, Чернігівську та Сумську області. Найнижчі з таких відхилень спостерігались у Хмельницькому $(-1,1)$, Новій Ушиці $(-0,9)$, Фастові $(-0,6)$, Білій Церкві $(-0,5)$, Олевську $(-0,6)$, Ромнах $(-0,7)$, Лебедині $(-0,5)$. Другий осередок від'ємних відхилень спостерігається майже паралельно першому в напрямі від південного заходу від сходу Одещини на північний схід через Миколаївську, Херсонську, Кіровоградську, Дніпропетровську, Запорізьку, Полтавську, Харківську та Луганську області. Найнижчі від'ємні відхилення спостерігались у Комсомольському $(-1,3)$, Біловодську (-0,9), Дніпрі $(-0,8)$, Комісарівці $(-0,9)$, Фотієвому $(-0,9)$, та Пришибі $(-0,8)$. Тільки на сході у Донецькій області в районі Волновахи спостерігався помітний осередок додатних відхилень $(+1,1)$. Також окремі осередки додатних відхилень, але значно менших, які не перевищують значення $+0,5$, помічено на півночі Чернігівщини (Семенівка), північному заході Луганщини, півдні Черкащини та Кіровоградщини, північному заході (район Болграду) та сході (район Любашівки) на Одещини (рис. 2).

Березень. Порівняно 3 періодом 2001-2010 pp. у п'ятиріччі 2001-2015 рр. додатні відхилення переважали на станціях 12 областей, а від'ємні у 10, здебільшого у центрі та подекуди на північному сході та півдні країни - Рівненській, Чернівецькій, Чернігівській, Сумській, Житомирській, Київській, Черкаській, Вінницькій, Луганській та Одеській областях. Також були Харківська область та АР Крим, де кількість станцій із додатними та від'ємними відхиленнями була рівною. На Закарпатті та ще 9 областях були станції, на яких також середня 
кількість випадків відкладень ожеледі не змінилась, - Львівська, Київська, Вінницька, Одеська, Сумська, Луганська, Дніпропетровська, Запорізька та АР Крим. З'ясовано, що найбільші з додатних відхилень $(+1,0 \ldots+1,8)$ середньої кількості випадків із відкладенням ожеледі у 2001-2015 pр. порівняно з 2001-2010 рр. помічались на станціях у Рівненській та Тернопільській областях. Найнижчі з від'ємних відхилень були незначними $(-0,6)$ і помічались на станціях у Львівській, Чернігівській, Сумській областях та АР Крим (рис. 2)

У березні 2011-2019 рр. порівняно з 2001-2010 рр. осередки додатних відкладень спостерігались здебільшого на сході України на території Харківської (особливо в районі Харкова, Краснограду, Богодухова, Великого Бурлуку), півночі в центрі Полтавської (Гадяч, Полтава, Веселий Поділ) та Кіровоградської (Знам'янка, Долинська), півночі Луганської (Троїцьке, Сватове), заході та півдні Донецької (Волноваха, Маріуполь), більшої частини Запорізької та південного сходу Херсонської (Хорли, Бехтери) областей. Найбільші значення додатних відхилень спостерігались у Донецькій області у Красноармійському $(+1,1)$, Волновасі $(+1,0)$, Харківській у Краснограді $(+0,9)$, Полтавській у Гадячі $(+1,0)$, Херсонській у Бехтерах $(+0,8)$, Кіровоградській у Знам'янці $(+1,0)$, а також на Тернопільщині у Тернополі $(+1,2)$ та Чорткові $(+0,8)$. Зменшення кількості випадків відкладень ожеледі спостерігалось на заході, північному заході України на території південної частини Львівщини, півночі Івано-Франківщини, півдні Закарпатської області, на Чернівеччині. Крім того, значний осередок від'ємних відхилень охопив територію із заходу на схід та північний схід від східної частини Волині -Рівненщину, Житомирщину, більшу частину Вінниччини, Київщину, Чернігівщину та Сумщину. Окремі осередки від'ємних відхилень середньої кількості випадків відкладень ожеледі спостерігались також на заході Черкащини, Кіровоградщини та Одещини, а також у районі крайнього південного сходу Херсонської області. Найнижчі значення таких відхилень були помірні -0,2 ..-0,4 (рис. 2).

Квітень. Порівняно з періодом 2001-2010 рр. у 2001-2015 рр. на більшості станцій середня кількість випадків із відкладеннями ожеледі залишалась незмінною. Однак у Сумській області переважають станції із від'ємними відхиленнями.

Протягом квітня 2011-2019 рр. порівняно з періодом 2001-2010 рр. на більшій частині території України середня кількість випадків відкладень ожеледі зменшилась або залишалась сталою, переважали незначні від’ємні відхилення (на Запоріжжі у Пришибі відхилення дорівнює -0,3). Осередки незначних від'ємних відхилень здебільшого спостерігались у центрі, на південному заході та подекуди на півдні. 
Жовтень. Порівняно 3 періодом 2001-2010 pp. протягом 2001-2015 pp. у більшості областей середня кількість випадків із відкладеннями ожеледі не змінилась, у 11 областях, тих самих, що і у вищезгаданих попередніх порівняннях, - Волинській, Хмельницькій, Тернопільській, Івано-Франківській, Чернівецькій, Вінницькій, Кіровоградській, Миколаївській, Херсонській, Дніпропетровській та Запорізькій - переважали станції з додатними відхиленнями. Це вказує на певну стійкість встановленої тенденції у часі.

У жовтні 2011-2019 рр. порівняно 3 попереднім десятиріччям 2001-2010 рр. здебільшого кількість випадків відкладень ожеледі майже не змінилась. Осередки незначних від'ємних відхилень $(-0,2 \ldots-0,3)$ здебільшого займали територію на півночі (південь та схід Київщини (Баришевка -0.2), північному сході країни (Чернігівська (Семенівка -0.2), Сумська, Харківська (Комсомольське -0,2), Полтавська (Полтава -0,2), схід Луганщини та подекуди у центрі (схід Черкаської області (Черкаси 0.3)). Незначні такі осередки спостерігались у центрі Рівненської області та на півдні Закарпаття. Осередки незначних додатних відхилень спостерігались у Вінницькій (Вінниця $+0,5$ ), Чернівецькій (Селятин $+0,4)$, Івано-Франківській (Пожежевська 0.6), Хмельницькій (Ямпіль, Хмельницькій $+0,4)$, Львівській (Рава-Руська $+0,5)$ областях, східній частині Хмельниччини.

Листопад. Порівняно з 2001-2010 pр. у 2001-2015 рр. збільшилось кількість областей із переважанням станцій із додатними відхиленнями середньої кількості випадків із відкладенням ожеледі до 17. Станції із від'ємними відхиленнями переважали лише в Полтавській області. У Чернігівській, Сумській та Одеській областях було порівну станцій із додатними та від'ємними відхиленнями. У 2001-2015 рр. порівняно 3 2001-2010 рр. найбільші з додатних відхилень становили $+1,0 \ldots+1,8$. Вони спостерігались на окремих станціях у 8 областях, переважно в центральних та східних областях. На заході станції 3 такими відхиленнями помічались у двох областях - Хмельницькій та ІваноФранківській. Найнижчі з від'ємних відхилень становили -0,6...-0,9, і спостерігались у трьох областях - Рівненській, Львівській, Харківській. Для окремих станцій від'ємні відхилення були ще нижчими -1,0. - Хутір Михайлівський (Дружба) та Донецьк (рис. 2).

Протягом листопада у 2011-2019 рр. найбільше збільшення середньої кількості випадків відкладень ожеледі (осередки додатних відхилень) спостерігалось у центральних, північно-східних та східних областях України $(+0,4 \ldots+0,8)$, частково на півночі. Найбільш помітний осередок таких відхилень спостерігався на заході в районі східної частини Хмельницької (Шепетівка. Хмельницький, Нова Ушиця) та Чернівецької (Чернівці, Ново-Дністровськ) областей $(+0,6 \ldots+1,2)$ та на Івано- 
Франківщині в районі Долини та Яремче. Особливо значні додатні відхилення спостерігались у низці пунктів - Ямполі $(+1,7)$, Чорткові $(+1,3)$, Тернополі $(+1,1)$, Долині $(+1,6)$, Селятині $(+1,1)$, Житомирі $(+1.3)$, Вінниці (+1.2), Сновську $(+1,2)$, Знам'янці $+1,0$, Помічній $(+1,3)$, Золочеві, Богодухові, Коломаку $(+0,7)$ Сватовому $+0,6)$, Артемівську $(+0,6)$, Комісарів ці $(+1,1)$, Кривому Розі та Лошкарівці $(+0,7)$. Осередки від'ємних відхилень середньої кількості випадків ожеледі спостерігались на Рівненщині, південному заході Львівщини, півночі Київщини, півночі Чернігівщини, північному сході Сумщини, півночі Харківщини, центрі та сході Одещини. Найбільш помітні значення таких відхилень спостерігались у Сарнах (-0,5), Дубно (-0.3), Семенівці (-0.4), Хуторі Михайлівському (-0,7), Чорнобилі та Баришівці (-0.4), Роздільній (-0.4).

Грудень. Порівняно з 2001-2010 pp. у 2001-2015 у більшості областей (15) переважали станції із додатними відхиленнями. Областей, де на станціях переважали від'ємні відхилення, було 8 - Волинська, Рівненська, Закарпатська, Одеська. Миколаївська. Сумська, Харківська та АР Крим. Ще у двох областях - Тернопільській та Луганській станцій із додатними та від'ємними відхиленнями було порівну. Найбільші 3 додатних відхилень становили $+1,0 \ldots+1,9$ і помічались у 13 областях. Проте найчастіше в областях - Закарпатській, Черкаській, Донецькій. Найнижчі з від'ємних відхилень становили $-1,1 \ldots-1,6$ і спостерігались у 5 областях - Київській, Миколаївській, Полтавській, Луганській, Донецькій (рис. 2).

Проведене порівняння середньої кількості відкладень ожеледі у грудні 2011-2019 рр. порівняно з 2001-2010 рр. показало наявність помітних центрів осередків додатних відхилень середньої кількості випадків відкладень ожеледі у низці областей - Закарпатській (Плай +1,1, Нижні Ворота $+1,3)$, на південному заході Львівщини (Турка $+1,1)$, центрі Житомирщини (Житомир +1,1), заході Вінниччини (Вінниця +1,2, Жмеринка $+1,1)$, центрі Хмельницькій (Хмельницький $+0,9$ ), Чернігівській (Семенівка $+1,0)$, півдні Кіровоградщини (Долинська $+1,0$ ), півночі Миколаївщини (Первомайськ $+1,1)$, сході та південному сході Херсонщини (Нова Каховка $+1,0$, Бехтери $+1,1)$, сході Харківщини (Комсомольське $+1,0$ ), півночі Луганщини (Новопсков $+1,5)$, заході Донеччини (Волноваха $+1,7$, Красноармійське $+1,2$ ), півдні Дніпропетровщини (Нікополь $+1,1)$. На решті території значення додатних відхилень були значно менші. Зменшення кількості випадків відкладень ожеледі спостерігались у різних регіонах України. Так, осередки від'ємних відхилень спостерігались у західних областях України. Найбільший із них охоплював територію півночі Волинської області, Рівненської, півночі Тернопільської, крайньої північно-західної частини Житомирщини. Також осередки від’ємних відхилень кількості випадків 
відкладень ожеледі спостерігались на території Львівщини у напрямі від північного заходу на південний схід у район Івано-Франківщини, де такий осередок займав майже усю область, а також та на крайньому південному заході Закарпаття в районі Мукачевого та Хуста. У північних, північно-східних, східних та центральних областях помітні осередки від'ємних відхилень спостерігались на півдні Київщини, у центрі та на сході Сумщини, північному сході Харківщини, півночі Дніпропетровщини, півночі Донецького регіону. Значний осередок таких відхилень спостерігався в районі півдня Кіровоградщини, більшої частини Миколаївщини (особливо в районі Миколаєва та Очакова) та південного сходу Одещини, а також окремий осередок на крайньому південному заході Одещини в районі Болграду та Ізмаїлу. Прикладом найнижчих значень таких відхилень є Маневичі $(-0,7)$, Рівне $(-0,6)$, Кременець (-0,7), Долина (-0,5), Біла Церква та Миронівка $(-0,6)$.

\section{ВИСНОВКИ}

Таким чином, з обговореного вище можна зробити певні висновки.

Так, у холодний період року порівняно з періодом 1991-2000 pp. протягом 2001-2010 та 2001-2015 pр. у більшості областей помічалась перевага станцій із додатними відхиленнями середньої кількості випадків відкладень ожеледі. У квітні та жовтні 2001-2010 pp. у більшості областей переважають станції, де середня кількість випадків відкладень ожеледі не змінилась. У жовтні 2001-2015 pр. збільшилась кількість областей, де переважають додатні відхилення середньої кількості випадків відкладень ожеледі.

Порівняно $з$ 2001-2010 pp. у 2001-2015 pp. у більшості областей спостерігались додатні відхилення середньої кількості випадків із відкладенням ожеледі, за виключенням лютого, в якому дещо переважають від’ємні відхилення.

Найбільші значення додатних та від'ємних відхилень помічались у січні, лютому, листопаді та грудні порівняно з 1991-2000 pр. у лютому 2001-2015 pp., листопаді 2001-2010 та 2001-2015 pp., порівняно 3 2001-2010 pp. у січні та лютому 2001-2015 pр. Порівняно з 1991-2000 pp. найбільше їх було в січні та лютому 2001-2010, 2001-2015 рр., грудні 2001-2010 та особливо 2001-2015 pp. Порівняно з 2001-2010 pp. найбільше таких значень спостерігалось у січні, листопаді та грудні 2001-2015 pp.

Протягом 2011-2019 pp. порівняно 3 періодом 2001-2010 pp. найбільші зміни у поширенні відкладень ожеледі на території України відбулись у січні, лютому, листопаді та грудні. У січні, листопаді та грудні збільшилась кількість відкладень ожеледі на більшій частині України. Осередки додатних відхилень середньої кількості випадків 
ожеледі найбільш виразно проявились у січні, де спостерігаються найбільші значення додатних відхилень у більшості осередків. У листопаді та грудні вони також широко поширені, проте значення відхилень дещо менше, ніж у січні. У лютому спостерігається тенденція до істотного зменшення кількості відкладень ожеледі на території України, яка підтверджує встановлену тенденцію для 2001-2015 pр. порівняно з 2001-2010 рр. У березні збільшилась кількість додатних осередків середньої кількості відкладень ожеледі та їх інтенсивність у центрі та особливо на сході країни, а також дещо зменшилась інтенсивність осередку на заході в районі Тернопільської та Хмельницької областей порівняно з 2001-2015 рр. У квітні та жовтні кількість випадків із відкладеннями ожеледі здебільшого змінились мало. Крім того, в цих місяцях спостерігається незначне зменшення їх кількості. Найпоширеніше зменшення їх кількості спостерігається у квітні здебільшого у західних, південно-західних та південних областях. У жовтні незначне зменшення кількості відкладень ожеледі спостерігається в північних та північно-східних областях.

\section{АНОТАЦІЯ}

Метою статті було дослідження та встановлення тенденцій у поширенні відкладень ожеледі, які спостережені інструментально на дротах стандартного ожеледного станка на території України протягом останніх 29 років по окремих місяцях холодного та перехідних сезонів року. Особлива увага була приділена останнім 9 рокам, які відтворюють сучасний стан поширення таких відкладень на сучасному етапі зміни клімату. 3'ясовано тенденції в поширенні середньої кількості відкладень ожеледі на території України протягом окремих періодів часу завдяки відхиленням наступного періоду від попереднього. Для сучасного періоду встановлено, що найбільші зміни у поширенні відкладень ожеледі у напрямі збільшення їх кількості відбулись у січні, листопаді та грудні 2011-2019 рр. порівняно з 2001-2010 рр. Зменшення кількості випадків відкладень ожеледі відбулось у лютому. Протягом окремих весняних та осінніх місяців (квітень, жовтень) поширення таких відкладень загалом змінилось мало. Крім того, натепер помічена тенденція зменшення їх кількості на досить значній частині території України.

\section{ЛIТЕРАТУРА}

1. Волеваха Н.М. О влиянии орографии на гололедные отложения. Труды УкрНИГМИ. Вып. 13. С. 82-86.

2. Кошенко А.М. Особо опасные гололеды на Украине. Tруды УкрНИГМИ. 1976. Вып. 134. С. 79-91. 
3. Климат Украины / Под ред. Г.Ф. Прихотько, А.В. Ткаченко, В.Н. Бабиченко. Ленинград : Гидрометеоиздат, 1967. 413 с.

4. Клімат України / За ред. В.М. Ліпінського, В.А. Дячука, В.М. Бабіченко. Ки: Вид-во. Раєвського, 2003. - 343 с.

5. Опасные явления погоды на Украине / Под ред. К.Т. Логвинова. Труды УкрНИГМИ. 1972. Вып. 110. 235 с.

6. Раевский А.Н. Влияние рельефа на распределение гололедноизморозевых отложений. Труды ОГМИ. 1961. Вып. ХХІІІ. С. 3-10.

7. Раевский А.Н. О распределении гололеда на территории Украины. Труды УкрНИГМИ. 1961. Вып. 29. С. 50-62.

8. Прохоренко М.М., Раевский А.Н. Особенности распределения гололедноизморозевых отложений на территории Украины в аномальные зимы. Метеорология, климатология и гидрология. 1975. Вып. 11. С. 33-37.

9. Природа Украинской ССР. Климат / Под ред. К.Т. Логвинова, М.И. Щербаня. Киев : Наукова думка, 1984. 231 с.

10. Пясецька C.I., Гребенюк Н.П., Щеглов О.А. Розподіл випадків відкладень ожеледі та небезпечної (НЯ) і стихійної (СГЯ) на території України в умовах сучасного клімату. Географія та туризм. 2018. Вип. 45. С. 120-132. DOI 17721/2308-135Х.2019.45.120-132.

11. Стихийные метеорологические явления на Украине и Молдавии / Под ред. В.Н. Бабиченко. Ленинград : Гидрометеоиздат, 1991. 223 с.

12. Стихійні метеорологічні явища на території України за останне двадцятиріччя (1986-2005рр.) / За ред. В.М. Ліпінського, В.І. Осадчого, В.М. Бабіченко. Київ : Вид-во Ніка-Центр, 2006. 311 с.

\section{Information about author:} Pyasetska S. I.,

$\mathrm{PhD}$ of Geographical Sciences, Senior Research Fellow at the Department of Climate Research and Long-Term Weather Forecasting Ukrainian Hydrometeorological Institute of the State Service of Emergencies of Ukraine and National Academy of Sciences of Ukraine 37, Nauky ave., Kyiv, 03028, Ukraine 